Kants Theorie der Erfahrung 



\section{Kants Theorie der Erfahrung}

Herausgegeben von

Rainer Enskat 
ISBN 978-3-05-005093-5

e-ISBN (PDF) 978-3-05-009023-8

e-ISBN (EPUB) 978-3-11-038022-4

\section{Library of Congress Cataloging-in-Publication Data}

A CIP catalog record for this book has been applied for at the Library of Congress.

\section{Bibliografische Information der Deutschen Nationalbibliothek}

Die Deutsche Nationalbibliothek verzeichnet diese Publikation in der Deutschen Nationalbibliografie; detaillierte bibliografische Daten sind im Internet über http://dnb.dnb.de abrufbar.

(C) 2015 Walter de Gruyter GmbH, Berlin/Boston

Druck und Bindung: $\mathrm{CPI}$ books $\mathrm{GmbH}$, Leck

Satz: Frank Hermenau, Kassel

@ Gedruckt auf säurefreiem Papier

Printed in Germany

www.degruyter.com 